UNIO - EU Law Journal. Vol. 3, No. 2, July 2017, pp 148-157.

®2017 Centre of Studies in European Union Law

School of Law - University of Minho

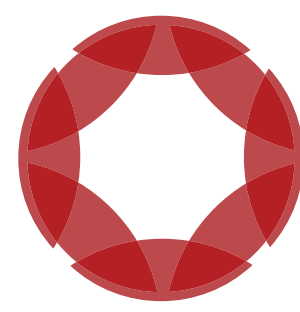

\title{
The transposition of the Private Enforcement Directive: a critical perspective
}

\author{
Maria José Costeira*
}

ABSTRACT: This article analyses the proposal of transposition of the Private Enforcement Directive into the Portuguese legal system. It examines several aspects of the preliminary draft, which went through public discussion, but it highlights, specially, the articles about definitions, liability, means of proof and the potential impacts it could have on the organisation of the Portuguese judicial system. It criticises the incoherencies and points out some problematic aspects of the proposal and the necessary amendments that should be made to make the law stronger.

KEYWORDS: Private Enforcement Directive - competition law - Portuguese legal system proposal of transposition - judicial organisation.

\footnotetext{
* Portuguese judge at the General Court of the Court of Justice of the European Union.
} 
On $26^{\text {th }}$ November 2014 was approved the Directive 2014/104/EU of the European Parliament and of the Council on certain rules governing actions for damages under national law for infringements of the competition law provisions of the Member States and of the European Union. That Directive, usually called Directive Enforcement, had to be transposed into national law by Member States by $27^{\text {th }}$ December 2016 (Article 21).

In Portugal, the National Competition Authority (Autoridade da Concorrência $-\mathrm{AdC})$, the entity in charge of preparing the transposition, presented, on the $22^{\text {nd }}$ June 2016, the last proposal of a preliminary draft for the transposition, which resulted from a process of public discussion.

Such last version is the one on which this paper is based. I intend to draw attention to some aspects that could be improved. Intentionally, for reasons of time and space, a few topics are left out of the analysis, as the quantum of damages or access to means of proof.

The analysis will be centred essentially on Article 2 (Definitions), Article 3 (Liability), Article 7 (Evidential Value) and Article 22 (Amendments to the statue of Organisation of the Judicial System).

\section{Article 2 - Definitions}

This article presents a number of definitions and concepts that are referred to over the text of the proposal, similarly to Article 2 of the Directive. It has been chosen to include definitions which are not given in the equivalent Article of the Directive, to alter their order and to supress others.

Concerning the inclusion of concepts absent in Article 2 of the Directive, the notions of cartel and of extra-judicial settlement - subparagraphs c) and r) must be highlighted.

\section{Subparagraph c) Cartel}

"Cartel, the agreement or concerted action between two or more competing companies which aims at coordinating their competition behaviour in the market or influencing the relevant competition standards through acts such as, namely, fixing or coordinating the prices of acquisition or sell or other conditions of transactions, including in relation to rights of intellectual property, attribution of production or sell quotas, sharing markets and clients, including the concertation in auctions and public procurements, restricting importations or exportations or conducting anti-competitive acts against other competitors as probibited by Article 9 of the Law $n^{\circ} .19 / 2012$, of $8^{\text {th }}$ May, and if applicable by Article 101, TFEU'.

The infractions of the competition law are enshrined in an autonomous statue: the Law of Competition ( $\mathrm{LdC}$ ), approved by the Law n. 19/2012 of $8^{\text {th }}$ May. The proposal I examine here does not intend to change, define or dispose in any other way, about the infractions, as expressively resulting from Article 1 and the Explanatory Statement of the proposal. It is at stake only the regulation of some aspects of the action for damages caused by infractions of competition law.

The inclusion of the notion of cartel in this preliminary draft, a typical infraction of the competition law, is at first unnecessary, given that such infraction is well defined in Article 9, LdC. Not only is it unnecessary, but it is also counterproductive once the characterisation of cartel is different from the notion in Article 9. That 
alone may provoke useless and pointless interpretation doubts.

\section{Subparagraph r) extra-judicial settlement}

"Extra-judicial settlement", any mechanism that allows the parties to extra-judicially resolve their dispute concerning the claim for compensation, namely mediation, conciliation, arbitration and the transaction foreseen in Article 1248 of the Civil Code".

Extra-judicial settlement is the generic designation to all forms of alternative dispute resolution in comparison to what we may call traditional or conventional form, which is recourse to court. Mediation, arbitration and conciliation are the typical forms of extra-judicial settlement. Transaction, on the other hand, could be an alternative form of resolution or not, i.e., transaction is possible, and I would say even frequent, during the course of legal proceedings. In that case, although it is an amicable and consensual form of settlement, it is not an extra-judicial settlement tout court, primarily because it depends on a judicial ruling of homologation.

The option to define the possible ways of extra-judicial settlement in a statue that intends to regulate some specificities of a determined sort of civil suit seems senseless, as if nothing had been provided for, they would all be possible.

It should be noted that the Directive defines "consensual dispute resolution" and not extra-judicial settlement. It does so as any mechanism of extra-judicial dispute settlement that allows the parties to reach an agreement as to the claim for damages (Article 2, paragraph 21) is allowed, which is considerably distinct than enunciating the forms of extra-judicial settlement.

Regarding the suppression of some definitions presented in the Directive, I draw attention to the definitions of "action for damages" and "claim for damages". One might ask: was it necessary to include those definitions? Maybe it was not. But it is certain that there was no need to define "extra-judicial settlement" (subparagraph a) or infraction of the competition law (subparagraph $\mathrm{k}$ ) neither and yet, definitions of these terms are given.

Concerning the change of nomenclature, the notions of final infringement decision and evidence must be considered.

\section{Subparagraph h) "final decision"}

"A decision of an authority of competition that cannot or can no longer be subjected to ordinary appeal".

It should be noted that the Directive does not define 'final decision', but instead, it defines 'final infringement decision', which refers to it as; "an infringement decision that cannot be, or that can no longer be, appealed by ordinary means". That is, it embraces decisions from national authorities and court judgements.

In the proposal, it is chosen to define only as a final decision, the decisions rendered by authorities of competition, making the writing of Article 5(3), para. B, 6(5), and 7 (1) and (2) more complicated and potentiating eventual controversies about an issue that does not merit discussion.

\section{Subparagraph o) "pre-existing information"}

"Evidence that exists irrespective of the proceedings of a competition authority, whether or not 
such information is in the file of a competition authority".

The Directive defines with the same content as the proposal, "pre-existing information" [Article 2 (17)].

Amongst us such designation, however, - "pre-existing information" - is not that common. Nevertheless, when we talk about 'pre-existing information', we mean pre-produced evidence, i.e., evidence produced before the beginning of the judicial case. The pre-existence is linked with the judicial proceeding.

As this is the concept of pre-existing evidence in our legal order, it seems rather incorrect to refer to pre-existing means of proof when alluding to means of proof that exist regardless of any AdC investigation, once they are not truly means of proof 'pre-existent to', but rather 'existent irrespective of.

\section{Article 3 - Liability}

This article, one of the most important, has some flaws that I consider problematic.

In paragraph 1, we read; "[t]he company or association of companies that commit an infraction of the competition law is obliged to fully compensate the ones who suffered harms caused by such infraction".

Article 3 of the Directive, under the title, "right to full compensation", states that: "Member States shall ensure that any natural or legal person who has suffered harm caused by an infringement of competition law is able to claim and to obtain full compensation for that harm".

The writing of the proposal of transposition is substantially different from the writing of the article of the Directive. Indeed, it is distinct to say that the harmed ones have a right to compensation or that the infringers are obliged to compensate the damages.

In this case, the writing of the Directive seems more appropriate because, in fact, the obligation to compensate only exists if, besides the infraction, the remaining elements of liability are proved, namely the damages and the causal link. Therefore, it cannot be said that the infringers hold a direct and immediate obligation of paying compensation. It is more adequate to say that the harmed ones are entitled to compensation.

The chosen writing makes way for the argument that, to make emerge the obligation to compensate when there are damages, it is enough to prove the infraction, which is not right, as being the proof of the causal link indeed essential.

It should be noticed that Recital 11 of the Directive, beyond referring expressively to the causal link, clarifies that "Where Member States provide other conditions for compensation under national law, such as imputability, adequacy or culpability, they should be able to maintain such conditions in so far as they comply with the case-law of the Court of Justice, the principles of effectiveness and equivalence, and this Directive".

In paragraph 2, we read "when a company includes a plurality of legal persons, the action of one of them is equally imputable to the legal person or persons that constitute an economic unity or keep interdependence links and that over it have exercised determining influence".

The intention of this provision is to encompass the groups of companies as provided for in Articles 488 and 489 of the Commercial Company Code (Código das Sociedades Comerciais) and hold the dominant company (parent company) accountable (as expressively derived from paragraph 3).

The terminology used is in disharmony with our traditional legal language. Indeed, in our legal order, expressions such as "plurality of legal persons" are not used, neither it is established that "the action of one legal person is equally imputable to another legal person".

In fact, neither the companies include a plurality of legal persons nor the 
infractions committed by a company are imputable to other. Companies are or might be in group relations or domain. On the other hand, it is not the imputation that is transmitted. What may be transmitted is the responsibility/liability resulting from the infringing action.

In accordance with the Commercial Company Code, the parent companies dominant company - are accountable for the obligations of the dominated companies - dominated society (Article 501, ex vi Article 491).

Considering paragraph 3 of this Article ("It is presumed that a legal person exercises determining influence over other legal person when it holds its total shareholding"), it seems clear that the intention is to refer to companies with a full domain relation. As a consequence, a composition more consistent with our legal language should be chosen.

\section{Article 7 - "Evidential value of the decisions of the competition authorities and court of appeals"}

According to paragraph 1 of this Article, "the declaration of the existence of an infraction of competition law by the Competition Authority through a definitive decision, or by a court of appeal through a final judgment, constitutes a irrebuttable presumption of the existence, nature and material, personal, temporal and territorial scope of such infraction for effects of the respective action for damages".

This article emerges from the transposition of Article 9 of the Directive and it can be said that, to a certain extent, it enshrines an enlargement of the range already envisaged in Article 16(1), of the Regulation 1/2003.

The result of this article, as it was already the result of aforementioned Article 16, respecting the Commission, is that in an action for infraction of the competition rules in which a definitive decision of $\mathrm{AdC}$ has been issued - confirmed in court in case of appeal -, the court cannot appreciate the existence of the infraction, i.e., the existence of the infraction is considered proved. That includes the elements of material, personal, temporal and territorial scope of such infraction. In the proposal, the choice is for the concept of irrebuttable presumption, which I believe is correct.

The legality of Article 16 was already questioned and, namely, its compatibility with Article 47 of the Charter of Fundamental Rights of the European Union (CFREU) -that assures, in the Union law, the protection conferred by Article 6(1) of the European Convention of Human Rights (ECHR) - that consecrates the principle of effective judicial protection. Such principle embraces the rights of defence, equality of arms, access to the courts and the right to ask for advice, defence and legal representation.

Indeed, one could ask if, when a court is prevented from appreciating the existence of an infraction, the right of effective judicial protection is being somehow limited, as the party is not allowed to defend him/herself on what the practice of the infraction is concerned since it is considered an established fact.

The Court of Justice has addressed that question, clarifying why Article 16 of the Regulation does not violate Article 47 of the Charter (Judgment Europese, C-199/11, of 6th November 2012).

In short, the reasons are the following:

1) An application of the EU competition rules is, thus, based on an obligation of Sincere Cooperation between the national courts, on the one hand, and the Commission and the EU Courts, on the other, in the context of which each act, on 
the basis of the role assigned to it by the Treaty (Masterfoods and HB, paragraph 56). It must be borne in mind in that regard, that it is the EU Courts - not the courts of the Member States - which have exclusive jurisdiction to review the legality of the acts of the EU institutions. National courts do not have power to declare such acts invalid [see, to that effect, Case 314/85 Foto-Frost (1987) ECR 4199, paragraphs 12 to 20] (paragraphs 52 and 53).

2) The rule that national courts may not take decisions running counter to a Commission decision relating to a proceeding under Article 101 TFEU is thus a specific expression of the division of powers, within the EU, between, on the one hand, national courts and, on the other, the Commission and the EU Courts (paragraph 54).

3) EU law provides for a system of judicial review of Commission decisions relating to proceedings under Article 101 TFEU which affords all the safeguards required by Article 47 of the Charter (paragraph 56).

4) The review provided for by the Treaties thus involves review by the EU Courts of both the law and the facts, and means that they have the power to assess the evidence, to annul the contested decision and to alter the amount of a fine. The review of legality provided for in Article 263 TFEU, supplemented by the unlimited jurisdiction in respect of the amount of the fine, provided for in Article 31 of Regulation No. 1/2003, therefore meets the requirements of the principle of effective judicial protection in Article 47 of the Charter (see, to that effect, Chalkor v. Commission, paragraph 67) (paragraph 63).

5) Finally, a civil action for damages requires not only that a harmful event be found to have occurred, but also that loss and a direct link between the loss and that harmful event be established. Because of its obligation not to take decisions running counter to a Commission decision finding an infringement of Article 101 TFEU, the national court is required to accept that where a prohibited agreement or practice exists, the existence of loss and of a direct causal link between the loss and the agreement or practice in question remains, by contrast, a matter to be assessed by the national court (paragraph 65).

Hence, although it is true that the obligation of the national judge to not take decisions contrary to the decision of the Commission that states an infraction of Article 101, TFEU forces this judge to conclude for the existence of a cartel or a prohibited practice, it is necessary to precise that the verification of damage and a direct causal link between that damage and the cartel or the prohibited practice continues subject to appreciation by the national judge.

The same reasoning can be transposed to the decisions of AdC. Leaving out the first series of arguments related with the duty of loyal cooperation between the institutions of the Union and the national legal organs as it is not applicable, the second series of arguments has full application. On one hand, the appeal of the $\mathrm{AdC}$ decisions to our national court is an unlimited jurisdiction appeal, ensuring that, if the infringer was not appeased with the decision and lodged an appeal, it had the right to an absolutely fair and impartial trial in which it could defend itself. On the other hand, it is in the action where compensation is claimed that the proof of the existence of damage and the causal link between it and the infraction should be made.

The principle of effective judicial protection is, thus, perfectly assured. 
The situation is different in paragraphs 2 and 3 of this Article:

" 2 - The declaration by an authority of competition of any Member State of the Union, through a definitive decision, of the existence of an infraction of the competition law constitutes a refutable presumption of the existence, the nature and the material, personal, temporal and territorial scope of such infraction for effects of the respective action for damages".

"3 - The declaration by the court of appeal of other Member State of the Union, through a final decision, of the existence of an infraction of the competition law constitutes a refutable presumption of the existence, the nature and the material, personal, temporal and territorial scope of such infraction for effects of the respective action for damages".

On the decision issued by authorities and courts of other Member States, the Directive imposes that they can be presented in court; "at least prima facie evidence that an infringement of competition law".

In the transposition of that precept, the national lawmakers conferred to the decisions of authorities and courts of other Member States the force of rebuttable presumption of the infraction.

Going back a little, the original writing of paragraphs 2 and 3 of this Article widened the binding and the nature of irrebuttable presumption to the decision of national authorities and the courts of other Member States. After the process of public discussion of the proposal, the nature of the presumption was altered to rebuttable.

Presumptions are, as Article 349 of the Civil Code states "the conclusions that the law or the judge deduces from a known fact to determine a unknown one". If the presumption is irrebuttable, the party that has it favourable does not need to adduce evidence of the fact to which the presumption leads. If it is rebuttable, it admits evidence to the contrary that is to be made by the one against whom the presumption works (Article 350, Civil Code).

That means that in a typical action for damages based on the infringement of competition law, the infraction is presumed and the burden is on the defendant(s) to demonstrate that, notwithstanding a previous conviction, the infraction did not exist.

Differently to what happens in the case of an enforceable decision of AdC, in this case, the enshrined option must be evaluated. Indeed, on one hand, in the universe of the 28 Member States, the national competition authorities do not have the same nature and independence. On the other hand, the regime of appeals of the national authorities decisions does not hold, in all Member States, the same nature of unlimited jurisdiction appeal. As a consequence, conferring to those the decisions the force of rebuttable presumption (specially because the refutability is very difficult) may conflict with the right to effective judicial protection.

\section{Article 22 - "Amendments to the Judicial System Organisation Law (Lei de Organização do Sistema Judiciário)"}

All the efforts and initiatives aiming at achieving a better efficacy and celerity in the solution of judicial cases must be praised and supported. The better efficacy and celerity depends, I believe, namely on the specialisation of courts and on the homogeneity in the interpretation and application of laws, which is indispensable for legal certainty. However, as those initiatives always entail a more or less deep change in the system of justice, they must reflect viable reforms, supported by concrete, effective and efficient measures. 
First of all it is important to emphasise an apparent contradiction between Article 1(1) of the project and the writing proposed to the new Article 112(4) of the Lei de Organização do Sistema Judiciário (LOSJ). It is a preliminary draft of transposition of a Directive that refers to the actions for damages, based on an infringement to the rules of competition law. That is expressly mentioned in what can be called the Preamble and reaffirmed in Article 1, which under the epigraph; "object and scope of application" clearly states that; "[t] he current act establishes rules concerning claims for compensation based on infringements of the competition law".

It seems that there are no doubts that the statue encompasses, exclusively, actions for damages, which is provided for in this article on its object.

It occurs that, besides the proposition to add a paragraph 3 to Article 122 of LOSJ, which regulates the actions for damages, it is also proposed to add a paragraph 4 in which the competence attributed to the Regulation, Competition and Supervision Court/Tribunal da Regulação, Concorrência e Supervisão (TRCS) would embrace; "all other civil actions". That means that the law goes beyond and has a broader object than it defines itself (the actions for damages based on infringements of the competition law).

The reasons that substantiate the proposal of amendment to the TCRS competence are, in theory and, in abstract, valid:

1) specificity of matters of competition law and economy and in the convenience that it is a specialised court to always handle with this sort of matters, to the benefit of quality of judicial rulings and, in more general terms, the good administration of justice and enhancement of the legal culture of competition in Portugal.

2) connection that, in most cases, will exist between the action for damages and the administrative offence suit which investigates and punishes the same infraction to the competition law, with the advantage of profiting from the know how acquired in the judgment of the $A d C$ 's decision that had declared the existence of the infraction, which will then base the claim for compensation.

The advantages of specialisation are evident in any jurisdiction and particularly in an area of law with the specificities of competition law. It allows a deeper knowledge of the matters and contributes to the uniformity of the case-law, assuring the harmony and coherence of the entire legal system.

Yet, when we analyse, in practice, the impact of the proposed new competence, it is possible to conclude that the reasoning is rather theoretical.

The proposal is to attribute competences to the TCRS in order to

"3 - judge actions for damages whose claim is exclusively based on competition law infringements ; actions aiming the exercise of the right of recourse amongst co-infringers as well as claims of access to means of proof relating to such actions in the terms stipulated in this law".

4 - It is still under the court's competence to judge all other civil actions whose claim is based exclusively in infringements of the competition law provided for in Articles 9, 11 and 12 of the Lei n. ${ }^{\circ}$ 19/2012, of $8^{\text {th }}$ May 2012, and/or Articles 101 and 102, TFEU'.

It should be noted that it is not established the attribution of competence of the TCRS to the measures of preservation of the means of proof which are stated in Article 17 of the proposal. As we know that the competence of "specialised" courts is solely the one written in law, with the residual jurisdiction belonging to the local division for civil matters (seç̃ões locais civeis). Therefore, it would be convenient to add this competence in paragraph 3 so that potential conflicts of jurisdiction are prevented.

Looking at the analysis of the amendments proposed to the TCRS competence, it is should be considered that, notwithstanding the fact that there will be a single specialised court to a part of actions and litigation related to competition law, there is still 
a large amount of cases, perhaps the majority, which stays away from the specialisation. In fact, all the cases in which the cause of action is not uniquely the competition law infringement, as well as the ones in which the competition law is invoked in the defendant pleading, i.e., most of the pending cases in our courts, are excluded from the TCRS' competence.

On the other hand, there is still a considerable number of cases that will remain in the administrative courts where the private enforcement actions have been increasing.

According to the study of the Centre for Research in European, Economic, Financial and Tax Law - CIDEEFF, ${ }^{1}$ the history of the actions of private enforcement in Portugal are the following:

"over the last 5 complete years (2011 to 2015), there was a total of 106 rulings on competition private enforcement (excluding the Instituto da Vinha), in an average of 21,2 peryear. In 2015 there were 212\% more rulings than in 2011. Even admitting an increase in the rising trend to $250 \%$ over the course of the next 5 years, by 2020 there would be a total of 265 rulings and an average of 53 decisions peryear, in all instances and all courts of the country. Those numbers are probably an optimistic estimative (...).

Hence, out of the 88 cases of restricting practises analysed, only 7, at the most, would fall under the competence of the TCRS thereby defined (less than 8\%). But, in one of these cases, the courts "amended" the claim of the plaintiff to other private law claim. And in three other cases it is possible that allegations of regulatory and/ or private law had been raised. Only one of the cases is not a follow-on or mixed action, and they are all recent actions, what may suggest an evolving process that leads in the future to a larger number of actions with that configuration.

That means that, in an optimistic preview (based on the maintenance of the same rbythm of AdC decision-making procedure), the clause of centralisation of cases in the TCRS will bring to this court about 3 cases a year, in average, over the next years, and the majority of the cases in which private enforcement issues are raised will continue to be heard in other courts of first instance".

Then, it seems clear that a true specialisation concerning the private enforcement actions will not take place.

Likewise, the proposed specialisation in the higher courts presents some flaws.

Currently, in first instance there is only specialisation for public enforcement. The AdC decisions are subjected to appeal to the TCRS and the appeal from its decisions are lodged in the Tribunal da Relação de Lisboa (Court of Appeal) where they are distributed always to the same criminal division. In turn, the remedies against the decisions rendered by the Tribunal da Relação de Lisboa lodged in the Supremo Tribunal de Justica (Supreme Court of Justice) are always distributed to the same criminal division, pursuant to Article 54 and 74 of LOSJ.

The proposal introduces amendments that I consider incoherent and that do not contribute to the specialisation of high courts.

The proposal of the writing of the Article 54, LOSJ is 'the cases referred in Article 112 are always distributed to the same criminal division, except for the cases mentioned in Article 112(2) to (4), which are always distributed to the same civil division'.

The proposal of writing of the Article 67, LOSJ is 'until the installation of the competition, regulatory and supervision division, the actions referred to in Article 112 are always distributed to the same division'.

\footnotetext{
${ }^{1}$ Available at: http://www.cideeff.pt/xms/files/Projeto_4_grupo_III/Jurisprudencia_de_Private_ Enforcement.pdf.
} 
In what concerns the Supremo Tribunal de Justiça, it derives from the proposal that the choice is for a specialisation in two different dimensions: private enforcement (civil) on one hand and public enforcement (administrative offence suits) on the other. That results from the proposal of amendment of Article 54, which expressly attributes the competences separately for the cases stipulated in Article 112(1) LOSJ (public enforcement) and in Article 112(2) to (4) (administrative offence suits and private enforcement) respectively to a criminal division and a civil matters division.

As for the Tribunal da Relação, it seems that the objective, until a competition, regulatory and supervision division is created, which I think will be unlikely to happen due to the short number of cases, is to attribute the competence to a single division. The question is to know to which division will be the competence attributed. Will it be to a civil matters division or to a criminal division? And who will determine the competent division? Will it be the President of the Tribunal da Relação to decide?

The different writing of this article in comparison with the proposal for Article 54 does not allow any other interpretation, namely, it does not allow one to understand that the intention is to split the administrative offence matter and the civil matter and to attribute the competence to the first, to a criminal division and to the second, to a civil division.

In conclusion, we will have a single court of first instance with competence to hear all the cases provided for in Article 112, a single division in the Tribunal da Relação de Lisboa with competence to hear the same cases, but then, at the Supreme Court level, that competence is shared between a criminal division and a civil division.

It seems to be in question not only the coherence of the system, but also the real specialisation of high courts. 